Boise State University

ScholarWorks

University Author Recognition Bibliography:

2019

The Albertsons Library

$9-2019$

\title{
Rural Accessibility, Rural Development, and Natural Disasters in Bangladesh
}

Saleh Ahmed

Boise State University

Elizabeth Eklund

University of Arizona

Ahmed, S. \& Eklund, E. "Rural Accessibility, Rural Development, and Natural Disasters in Bangladesh", Journal of Developing Societies, 35(3), pp. 391-411. Copyright @ 2019, Sage Publications. Reprinted by permission of SAGE Publications. doi: 10.1177/0169796X19868318 
This is an author-produced, peer-reviewed version of this article. The final, definitive version of this document can be found online at Journal of Developing Societies, published by SAGE. Copyright restrictions may apply. doi: 10.1177/0169796X19868318

\title{
Rural Accessibility, Rural Development, and Natural Disasters in Bangladesh
}

\author{
Saleh Ahmed* \\ School of Public Service \\ Boise State University \\ salehahmed@boisestate.edu \\ Elizabeth Eklund \\ School of Anthropology \\ University of Arizona
}

\begin{abstract}
Rural accessibility means more than just reliable roads and cost-effective transportation networks in low-income developing countries. Rural accessibility is critical for achieving social and economic development in low-income developing countries such as Bangladesh where both rural and urban development are constrained by significant infrastructural deficiencies. It is also an important factor that determines the effects of natural disasters on these resource-constrained societies, since both disaster responses and sustainable development are compromised by poor rural accessibility. Using two contrasting case studies from Bangladesh, this article reveals the significance of improved rural accessibility on rural development and the effects of natural disasters on rural areas. The findings of this article suggest that the improvement of rural accessibility should be a top national development priority, since it increases the opportunities for sustainable social and economic development and reduces the adverse effects of natural disasters on the rural areas in developing countries such as Bangladesh.
\end{abstract}

Keywords: rural accessibility, rural development, disaster preparedness, Bangladesh, United Nations Sustainable Development Goals (UNSDGs)

\section{Introduction}

Despite rapid urbanization, rural communities will account for 30 percent of the world's population by 2030, the target year for the achievement of the United Nations Sustainable Development Goals (UNSDGs). In the last five decades, countries around the world have gained unprecedented economic growth. However, wealth disparities remain high in these countries (Njenga \& Davis, 2003). In most developing countries many rural areas are remote, resourceconstrained, and have limited accessibility —all of which limit the opportunities for local employment and reduce access to basic services such as healthcare and education (Atuoye et al., 2015).

The majority of the rural people in the Global South rely on subsistence farming or fishing (Rapsomanikis, 2015). For these rural people, rural accessibility is a critical factor affecting their livelihoods. Simply stated, rural accessibility involves peoples' ability to travel and exchange goods between particular destinations and use the available rural infrastructure as the means to do this (Edmonds, 1998). Poor accessibility involves more than just poor rural roads. Generally, poor accessibility involves a combination of inadequate transportation infrastructure, the absence of appropriate and affordable means of local transport as well as geographical remoteness, and isolation from healthcare services, education, and employment (Njenga \& Davis, 2003).

These conditions are prevalent in Bangladesh, since the majority of the population are poor and a large share of them live in remote rural areas with poor accessibility to affordable means of transportation and adequate roads. Their livelihoods are heavily dependent on farming and fishing. And since the country is increasingly exposed to various extreme weather and climate anomalies, millions of people are at a high risk of continued or even greater impoverishment (Parvin, Shimi, Shaw, \& Biswas, 2016). 
This is an author-produced, peer-reviewed version of this article. The final, definitive version of this document can be found online at Journal of Developing Societies, published by SAGE. Copyright restrictions may apply. doi: 10.1177/0169796X19868318

Even though there is substantial data on rural accessibility, 1 relatively few studies show how improved rural accessibility can contribute to disaster preparedness and risk reduction in general. This article focuses both on rural socioeconomic development and disaster preparedness, as well as the implications for achieving the United Nations 2030 Sustainable Development Goals. It does this by examining two contrasting case studies from rural Bangladesh.

The first case examines the social and economic impact of improved accessibility in rural communities in southwest Bangladesh. This region has a relatively higher poverty rate than many other parts of the country (Foley \& Chowdhury, 2007). In contrast, the second case study location is in coastal Bangladesh, which is even more remote and vulnerable to climate change impacts. Here people are dependent on subsistence agriculture, fishing and other resource-dependent activities such as honey and firewood collection (Ahmed \& Cokinos, 2017). Because of their exposure to natural disasters, people need weather and climate information including early warning on a constant basis. They need this information so they can go to cyclone shelters-if they have adequate rural roads and local transport. In most cases due to poor accessibility, the local people are unable to reach the cyclone shelters in a timely manner, which substantially contributes to the number of casualties caused by extreme weather events, such as cyclones.

The findings in this article draw upon more than a decade of engagement in development programs in southwest and coastal Bangladesh, and working with local communities, local governments, and non-governmental organizations (NGOs) in various capacities. More particularly, several empirical research trips were undertaken between 2007 and 2017 and during that period, qualitative research (e.g., focused group discussions and in-depth case study field research) as well as quantitative research (based on data obtained in structured and semistructured interviews) were conducted in local communities both in southwest and coastal Bangladesh to understand the impact of rural accessibility in both contexts. In many developing societies, rural accessibility projects are conceived as infrastructure projects that contribute to community development. But very few of them are integrated into a nation's overall efforts to reduce natural disaster impacts or to contribute to the achievement of the 2030 UNSDGs. This study attempts to contribute to the achievement of these goals in Bangladesh.

Since increasingly people in different parts of the world are facing various climate-related hazards, there is an acute need for a policy and paradigm shift, which considers rural accessibility not only as a contributor to socioeconomic development but also an instrument for disaster risk reduction. Even though geographically this article focuses on Bangladesh, the overall arguments presented in this article have strong policy relevance for other parts of the developing world facing similar social-environmental challenges.

\section{Rural Accessibility and Development}

Development theory in the 1960s was greatly influenced by Rostow's Stages of Economic Growth, which argued that every society would need to pass through a number of different stages in its economic development to achieve the levels of development of the Western countries (Rostow, 1959). In order to accelerate this process, large-scale infrastructure projects, including roads, were recommended and undertaken. However, in the 1970s, the emphasis shifted to human development, which emphasized social as well as economic development. In this case, it can be argued that roads provide people with the accessibility they need in order to flourish by engaging in different meaningful income earning opportunities. In the 1980s, Sen's works on human capability, entitlements, and freedoms became central to the development discourse, and this was incorporated into the United Nations Development Program's yearly flagship report named the "Human Development Report” (Pieterse, 2009). Sen argued that people's lack of entitlements, by which he meant their access to the means for providing the necessities of life, such as ownership of land or access to wage employment, were key determinants of poverty and vulnerability to disasters (Sen, 1999). Within Sen's theoretical framework, roads hold the potential for expanding human capabilities but only if the issue of entitlements is also addressed so that people can benefit from the improved infrastructure.

In recent years, the emphasis has shifted once more to a focus on how to balance our present time, resources, and physical inputs without limiting the opportunities for the future. The issue of good stewardship of the world's resources, which barely featured in Rostow's theory of economic growth, has assumed central stage. Stewardship should be understood to include both a fair sharing of the world's resources and sustainable use of those resources. In this context, improving accessibility and road construction are compatible with this sustainability approach to development since it enables people with the least access to resources to build resilience thereby rendering their livelihoods more sustainable. 
This is an author-produced, peer-reviewed version of this article. The final, definitive version of this document can be found online at Journal of Developing Societies, published by SAGE. Copyright restrictions may apply. doi: 10.1177/0169796X19868318

The shift from an economics focus to a more sophisticated social justice and sustainability focus is reflected in the United Nations Millennium Development Goals (UNMDGs) and then the 2030 UNSDGs. The UNMDGs played a pivotal role in shaping national development agendas in many countries and achieved substantial progress in human development (Hogan et al., 2010). However, UNMDGs had mixed outcomes between countries and within countries (Ahmed, 2017).

In the context of the post-2015 development agenda, rural accessibility plays a major role in achieving relevant development targets. People in remote rural areas usually face challenges due to their locational isolation, which often reinforce their impoverished situation (Chambers, 1983). Poor accessibility increases transport and agriculture costs substantially, and at the same time increases the prices of consumer goods in structurally challenged rural areas, where people are already exposed to various other development challenges (Njenga \& Davis, 2003). Lack of transportation reduces availability and quality of rural health services, education, and the provision of water and agriculture extension services (Gutierrez, 2009; Njenga \& Davis, 2003). Thus, accessibility refers to peoples' ability to obtain desired goods, services, and other resources.

The regions analyzed in this article — southwest and coastal Bangladesh — exhibit diverse geographical and economic features that exacerbate local and regional poverty. The study areas are far from regional or national economic hubs or markets and at the same time, particularly coastal Bangladesh, is heavily exposed to climatic stresses such as unpredictable rainfall patterns, heat waves, sea level rise, tropical cyclones, coastal and riverbank erosions, salinity intrusions, and coastal flooding. Therefore, these case studies not only demonstrate the value of rural accessibility in varied socio-environmental contexts, but also highlight the complex but dynamic relationships among climate, society, and economy.

\section{Case Study 1: Rural Accessibility Catalyzes Employment and Opportunities}

This case study focuses on the social and economic values of improved rural accessibility in Chuadanga district, which is in the southwest region of Bangladesh (Figure 1). Even though the region had political importance during the British Indian Era and the liberation war in 1971, in recent years Chuadanga has experienced a low level of economic investment, a decaying industrial base, is less favored politically, and is weakly integrated into the nation state and into its markets. Approximately, 1.1 million people (BBS, 2011) live in Chuadanga in its $1170.87 \mathrm{~km} 2$ (Bangladesh National Portal, 2016).

Previously, the absence of appropriate and adequate road infrastructure was one of the major developmental challenges in the region. This had not only impacted local accessibility to markets, employment, and other opportunities, but also created long-term poverty challenges, which caused low performance in various human development indicators such as maternal and child health, access to education, and legal supports. Local communities in this region are mostly agro-based (BBS, 2011) and a large share of the local population either are smallholder farmers or work on other's lands as day labors. For the local farmers, linking with rural markets is important, because in that way they can sell their products and can buy raw materials, fertilizers, and small agricultural equipment in a cost-effective manner. The absence of rural accessibility causes limited economic opportunities for the local communities by leaving people in a classic spatial poverty trap. 
This is an author-produced, peer-reviewed version of this article. The final, definitive version of this document can be found online at Journal of Developing Societies, published by SAGE. Copyright restrictions may apply. doi: 10.1177/0169796X19868318

Figure 1.

\section{Chuadanga District}

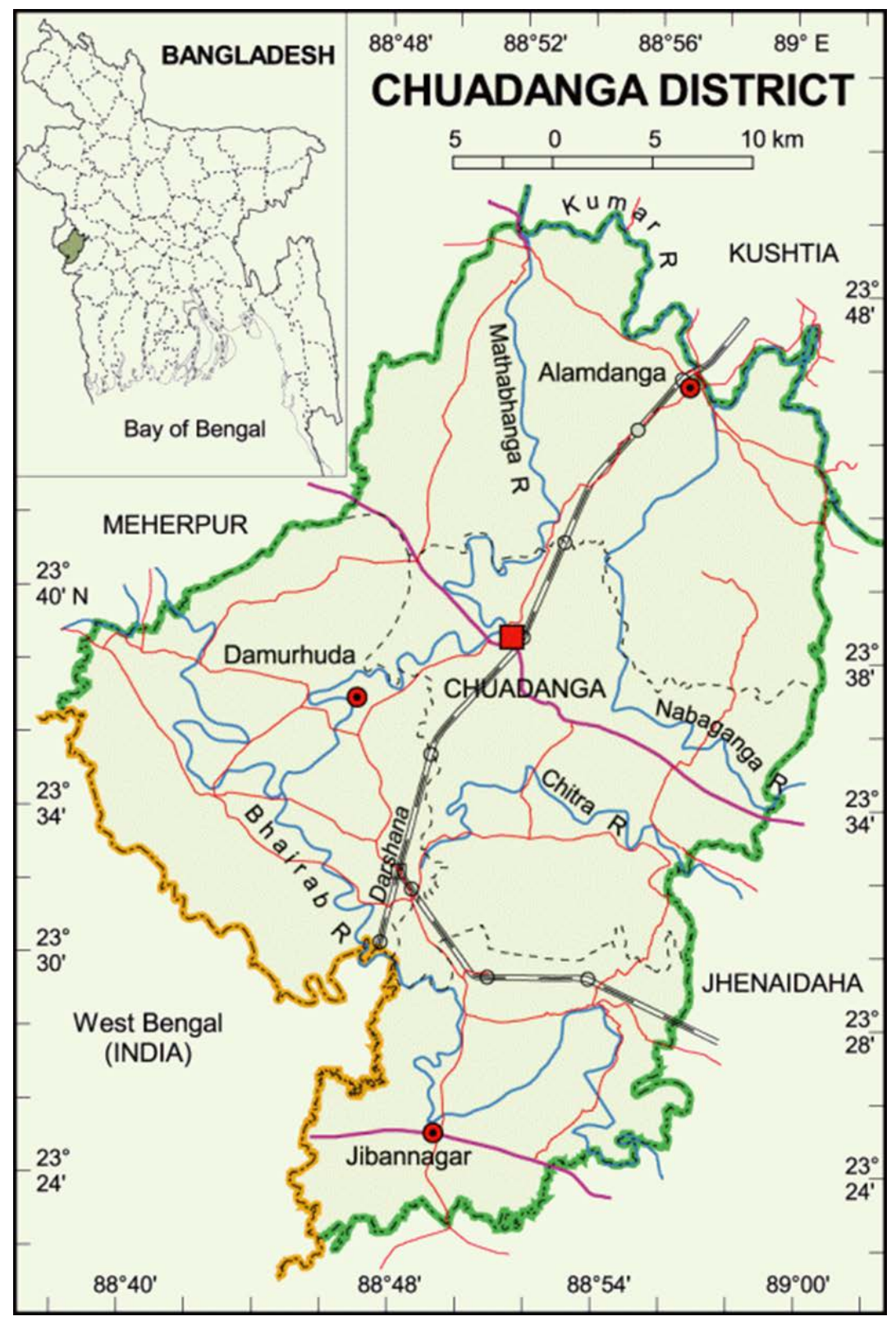

Source: BDmaps.com (Open Source)

\section{Implications of Improved Rural Accessibility in Chuadanga}

In an attempt to break out of the negative spiral of poverty, unemployment, and poor accessibility, the government of Bangladesh attempted to invest heavily in improving the rural infrastructure during the last several years. An example is the Rural Infrastructure Improvement Project (RIIP). Phase 1 took place from July 2003 to June 2010; and Phase 2 ran afterwards in south and southwest Bangladesh. The Local Government Engineering Department (LGED) under the Ministry of Local Government, Rural Development and Cooperatives initiated the project with financial support from the Asian Development Bank (ADB), the Federal Republic of Germany through the German Financial Cooperation (KfW), and German Technical Cooperation Agency (GTZ). 
This is an author-produced, peer-reviewed version of this article. The final, definitive version of this document can be found online at Journal of Developing Societies, published by SAGE. Copyright restrictions may apply. doi: 10.1177/0169796X19868318

The major goal of this project was "to reduce rural poverty through sustainable economic growth, rural development and improved infrastructure” (Kuhnle, 2005). More particularly, RIIP aimed to improve rural road infrastructure, develop rural growth centers, and rural markets as well as facilities for boat landings, ferries, and union council office (local government offices) complexes, and improve local institutional capacity to implement and manage similar kinds of development projects. This project was designed in such a way that impoverished populations, including both men and women, could participate in planning, implementation and management in a very collaborative environment. In addition, RIIP required the direct engagement of skilled, semiskilled, and unskilled road construction workers during the implementation phase, which created a huge demand for local labors from the surrounding villages. Targets were set for participation of women as well as men in program implementation. As a result, many poor and marginalized women and men got wage employment through the process. The impacts of the RIIP were significant and went beyond anticipated outputs (Ahmed \& Nahiduzzaman, 2016). Some of the impacts are discussed below with details.

\section{Employment Creation}

Road construction during the project implementation phase (Phase 1: July 2003 to June 2010) created 40,037 person years of employment. In addition, it is expected that RIIP will help create 42,000 person years of employment in next 20 years for road maintenance purpose, and 75 percent of these employments are targeted for extremely poor women (KfW, 2012), which are the most marginalized and excluded from

Figure 2.

\section{Road Construction and Ongoing Repair in the Chuadanga District Increased Employment Among Both Male and Female Laborers}

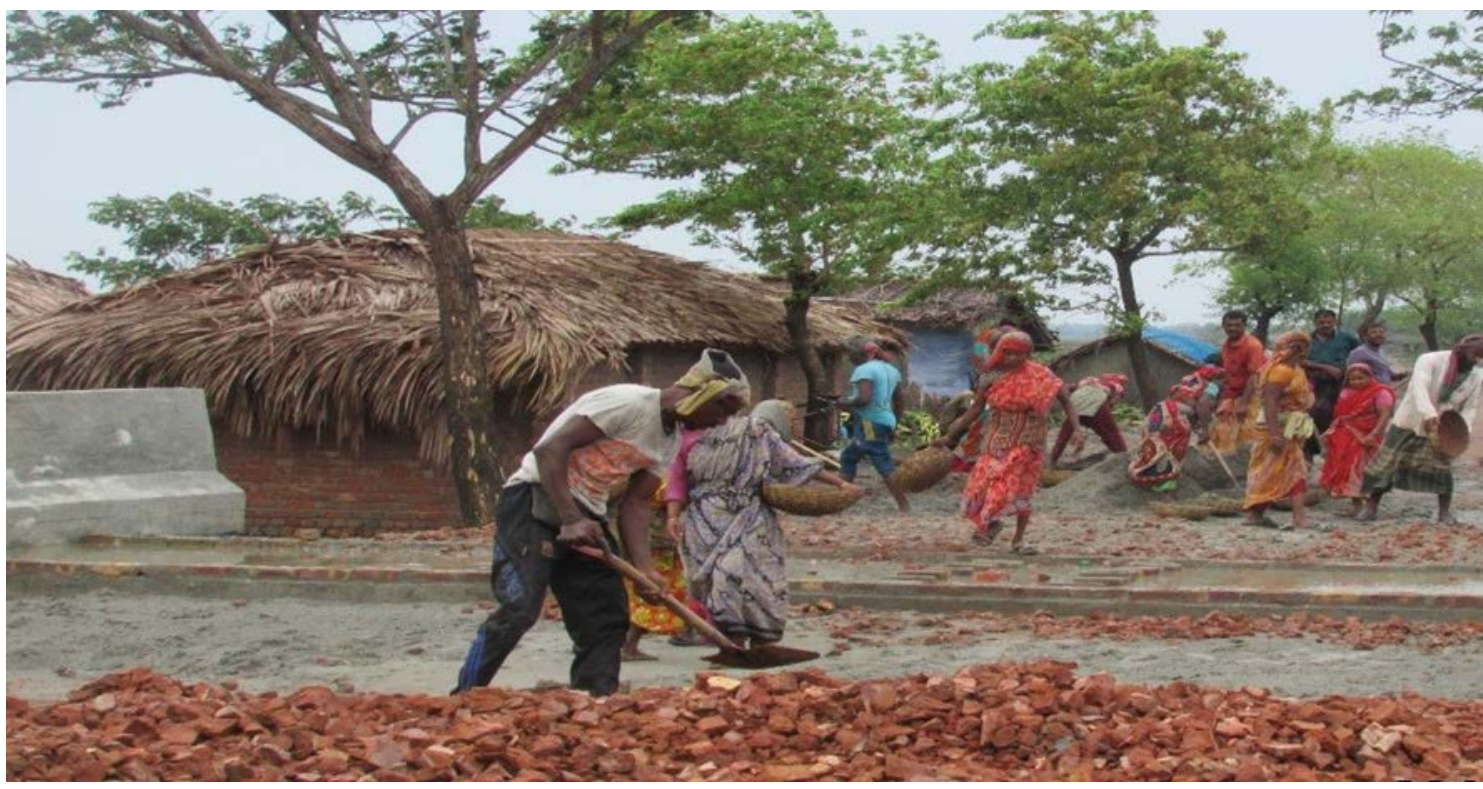

Source: The authors

mainstream economic activities. These women are usually extremely poor, and often most marginalized in the society. RIIP contributed to enhance household-level consumption including expenditure on health, education, and investments in various micro-, small-, and medium-size enterprises. In total, 94 percent people who were interviewed from the adjacent villages of RIIP reported that their wage employments now range from 200 to 365 days per year, which was substantially higher than pre-road construction time (Ahmed \& Nahiduzamman, 2016). Most of their employments came through the participation in road construction, road maintenance, and improved access to rural markets (Figure 2). 
This is an author-produced, peer-reviewed version of this article. The final, definitive version of this document can be found online at Journal of Developing Societies, published by SAGE. Copyright restrictions may apply. doi: 10.1177/0169796X19868318

\section{Gender Division of Labor}

Out of the 40,037 jobs in road construction created by the RIIP, 22 percent were given to local female workers (KfW, 2012). This improved their wage incomes, as well as contributed overall social and economic empowerment and development. In rural Bangladesh, employment opportunities for women are usually limited. For extremely poor women, opportunities exist even less because of the socio-cultural perceptions. Due to the absence of livelihood opportunities and satisfaction of their basic needs such as food, nutrition, and healthcare, some of the extremely poor women have limited cognitive and learning skills, which contribute to negative social and cultural perceptions that they are not employable or have no required skills to accomplish certain kinds of work.

\section{Economic Investment}

Local communities experienced increased public and private investments after the implementation of RIIP in this area. Generally, women in this area are famous for their handicrafts and boutiques (Figure 3). However, previously due to poor market linkages and poor accessibility, it was very challenging for them to sell to outside markets. At the same time, there were very few outside investments from public or private sectors for local enterprise development. Now after improved rural accessibility, women can easily sell their products to local markets and at the same time various outside investors came in and invested in the local handicrafts business.

Since this rural road project-RIIP—connected a large section of the local population to the mainstream economy, gradually people in the area were able to improve their own socioeconomic conditions and well-being, and they also created further local employment opportunities. The rate of illiteracy has also decreased in the project area. School enrollment of the children from poor impoverished families had been low before but with the improved accessibility it increased (Ahmed \& Nahiduzzaman, 2016). One of the reasons for the previous low school enrollment was the limited financial capacity to send the children for schooling, and at the same time poor rural connectivity between places played a decisive role.

Figure 3.

\section{Some of the Local Crafts Made in Chuadanga}
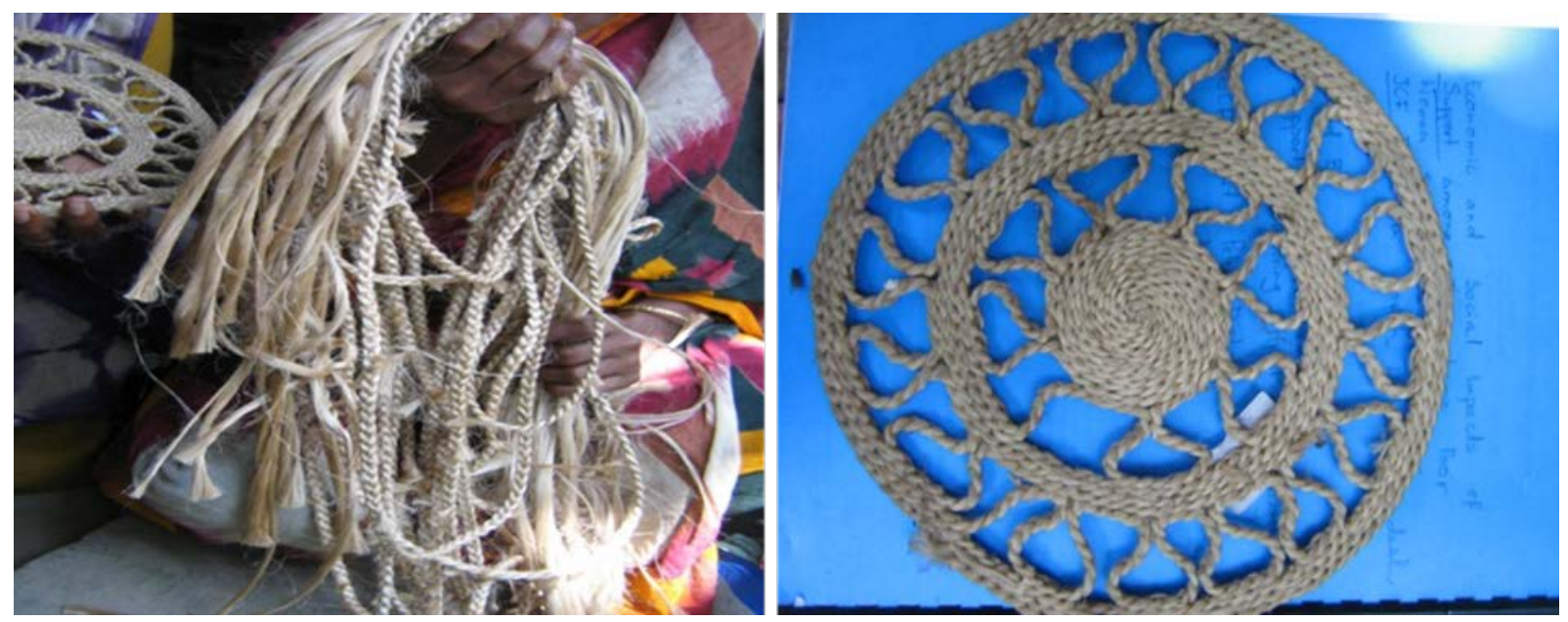

Source: The authors

However, with improved accessibility many of the local structural barriers were removed and the increased financial capacities at individual, household, and communal level made it possible to send their children to schools.

\section{$\underline{\text { Investment in Social Services }}$}

Improved rural accessibility in Chuadanga encouraged various small and large NGOs to come and work with the local communities. This had previously been almost impossible due to poor accessibility. Improved access to NGO services not only provided financial resources to local poor (Kotir \& Obeng-Odoom, 2009), but also provided opportunities to 
This is an author-produced, peer-reviewed version of this article. The final, definitive version of this document can be found online at Journal of Developing Societies, published by SAGE. Copyright restrictions may apply. doi: 10.1177/0169796X19868318

actively participate in various NGO supported skill development trainings (Ahmed \& Nahiduzzaman, 2016) as well as rural development in general (Kotir \& Obeng-Odoom, 2009). Many of them got engaged in range of nonfarm employments because of these skills development trainings. Diversity of income is a major criterion for increased social, economic, and environmental resiliency in any context (Darnhofer, 2010).

\section{Implications of Improved Accessibility on the UNSDGs}

Achievement of the UNSDGs is critical for countries like Bangladesh, since these goals provide benchmarks for success on how countries are doing on various development indicators. Previously Bangladesh made major progress toward the UN Millennium Development Goals despite the country's number of development uncertainties such as adverse impacts of global environmental change, poor governance and confrontational politics, weak civil society, and stable economy (Ahmed, 2017). The deadline for achieving the targets of the UNSDGs is just little more than a decade away. It is critical now to mainstream development interventions under the overall UNSDGs umbrella. For achieving national level targets on UNSDGs, it is critical to have success at the local level. Insights from Chuadanga reveal how improved rural accessibility can contribute to the targets associated to the UNSDGs (see Table 1).

In addition to the mentioned goals, RIIP also contributed indirectly to the UNSDG Goal 12 (Responsible Consumption and Production), Goal 13 (Climate Action), Goal 14 (Life below Water), and Goal 15 (Life on Land). It is important to remember that impacts on one goal can have cascading impacts on other goals. For example, increased education can 
This is an author-produced, peer-reviewed version of this article. The final, definitive version of this document can be found online at Journal of Developing Societies, published by SAGE. Copyright restrictions may apply. doi: 10.1177/0169796X19868318

\begin{tabular}{|c|c|c|c|}
\hline Theme & $\begin{array}{l}\text { Activities under } \\
\text { improved rural } \\
\text { accessibility }\end{array}$ & UNSDGs & Comments \\
\hline \multirow[t]{13}{*}{$\begin{array}{l}\text { Increased } \\
\text { employment }\end{array}$} & \multirow{13}{*}{$\begin{array}{l}\text { - } 42000 \text { person years } \\
\text { of employment in the } \\
\text { next } 20 \text { years for } \\
\text { road maintenance } \\
\text { - } 94 \text { percent people } \\
\text { were engaged in } \\
\text { wage employments } \\
\text { for } 200-365 \text { days per } \\
\text { year } \\
\text { - } 22 \text { percent of jobs } \\
\text { in road construction } \\
\text { created by the } \\
\text { project were taken } \\
\text { by female workers }\end{array}$} & Goal 1: No Poverty & Even though still there are poverty, but increased employment contributed to reduce poverty \\
\hline & & Goal 2: Zero Hunger & Employment opportunities contributed to reduce hunger among local populations \\
\hline & & $\begin{array}{l}\text { Goal 3: Good Health and Well- } \\
\text { being }\end{array}$ & $\begin{array}{l}\text { Due to increased income and employment opportunities, people have more disposable money } \\
\text { for health and nutrition }\end{array}$ \\
\hline & & Goal 4: Quality Education & $\begin{array}{l}\text { Due to improved accessibility, people have easier access to education and many skill } \\
\text { development opportunities }\end{array}$ \\
\hline & & Goal 5: Gender Equality & $\begin{array}{l}\text { Since a large share of the laborers are poor impoverished women, their employment } \\
\text { opportunities contributed to reduced gender gaps and empowered them socially and } \\
\text { economically }\end{array}$ \\
\hline & & $\begin{array}{l}\text { Goal 6: Clean Water and } \\
\text { Sanitation }\end{array}$ & Since local people had more income then before, they could afford clean water and sanitation \\
\hline & & $\begin{array}{l}\text { Goal 7: Affordable and Clean } \\
\text { Energy }\end{array}$ & Many local people were able to get access to clean energy because of their increased income \\
\hline & & $\begin{array}{l}\text { Goal 8: Decent Work and } \\
\text { Economic Growth }\end{array}$ & $\begin{array}{l}\text { Increased employment contributed to economic growth in the area, and because of } \\
\text { accessibility to services and opportunities, many people have better work conditions than } \\
\text { before }\end{array}$ \\
\hline & & $\begin{array}{l}\text { Goal 9: Industry, Innovation, } \\
\text { and Infrastructure }\end{array}$ & $\begin{array}{l}\text { RIIP attracted investment for micro, small and medium size enterprises. Also created space } \\
\text { for various social and livelihood innovations }\end{array}$ \\
\hline & & Goal 10: Reduce Inequality & $\begin{array}{l}\text { Since this project provided employments to the extremely poor women, who are the most } \\
\text { marginalized and impoverished in society, employment opportunities among the female } \\
\text { workers contributed to reduce inequality }\end{array}$ \\
\hline & & $\begin{array}{l}\text { Goal 11: Sustainable Cities and } \\
\text { Communities }\end{array}$ & Increased employment and income opportunities created avenues for sustainable communities. \\
\hline & & $\begin{array}{l}\text { Goal 16: Peace, Justice and } \\
\text { Strong Institutions }\end{array}$ & $\begin{array}{l}\text { RIIP contributed to develop local institutions and social justice and peace by engaging local } \\
\text { people into the process of road construction. }\end{array}$ \\
\hline & & $\begin{array}{l}\text { Goal 17: Partnerships for the } \\
\text { Goals }\end{array}$ & RIIP contributed partnerships in various scales ranging from international and local. \\
\hline
\end{tabular}

Source: The authors 
This is an author-produced, peer-reviewed version of this article. The final, definitive version of this document can be found online at Journal of Developing Societies, published by SAGE. Copyright restrictions may apply. doi: 10.1177/0169796X19868318

positively influence maternal and children's health (Koch et al., 2012). Improved rural accessibility in Chuadanga is one of the key examples that demonstrate how rural roads in resource-constrained environment can make meaningful contributions toward to the national efforts of achieving the UNSDGs.

\section{Case Study 2: Poor Accessibility and Challenged Local Development Efforts}

This case study presents evidence from Kalapara, which is a subdistrict (locally called "Upazila") of Patuakhali district (Figure 4). Geographically, Kalapara is one of the most vulnerable and disaster-prone upazila in Bangladesh. People here are at constant risk to tropical cyclones, coastal flooding, sea level rise, coastal erosion, rainfall unpredictability, and heat waves (Government of Bangladesh [GoB], 2014). It is relatively less densely populated area than the rest of Bangladesh, because of its remoteness, poor connectivity, and disaster exposures.

\section{Figure 4.}

\section{Kalapara in Patuakhali District}

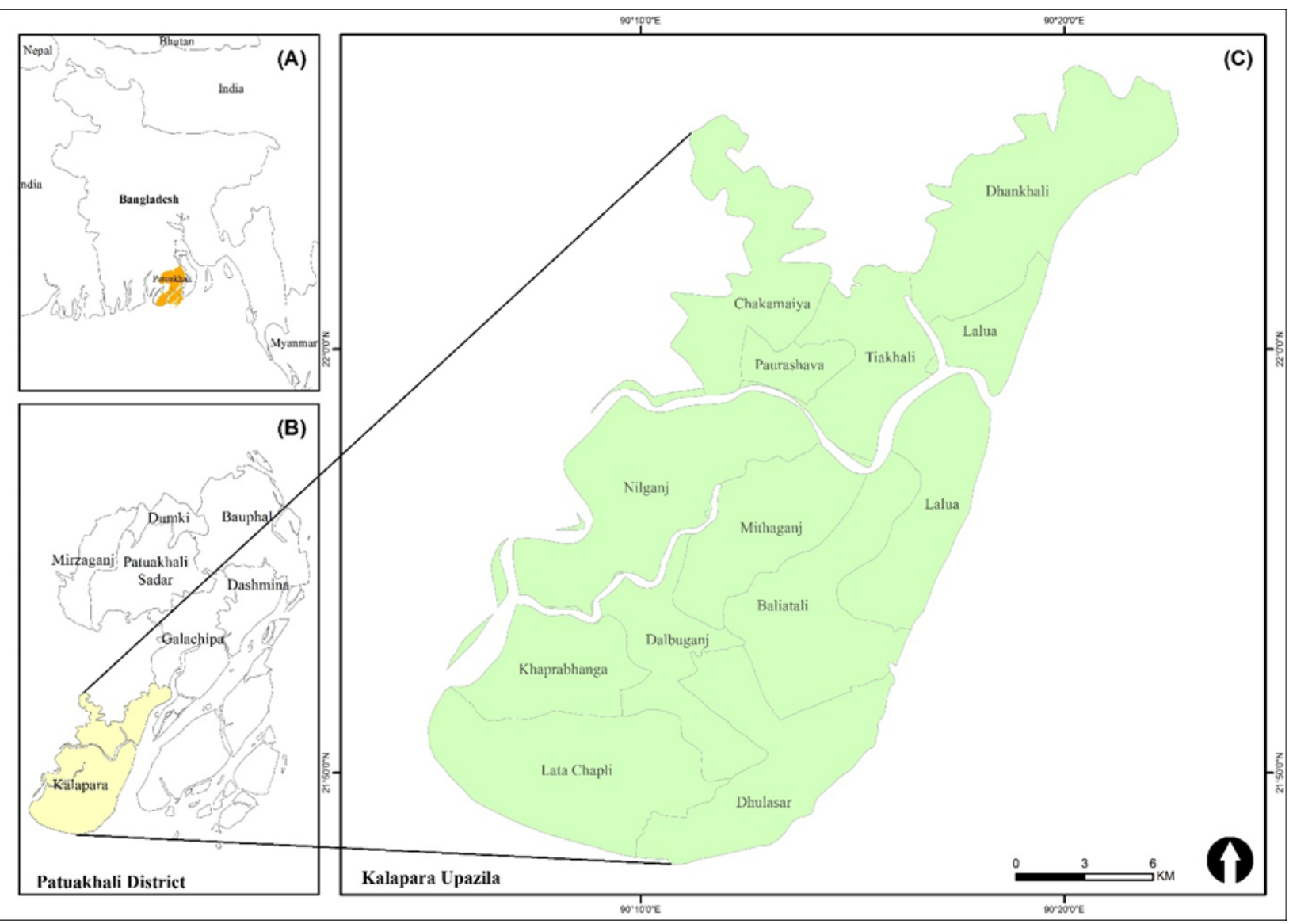

Source: The authors

Kalapara is approximately $492 \mathrm{~km} 2$ in size with a population of 238,000 (BBS, 2012). Local communities practice diverse livelihoods that include farming, fishing, and some forest-dependent activities such as honey collections, and other natural resource extractions, even though small-scale traditional farming is the most common livelihood option in the area (Hoque, 2014). Despite their dependency on farming, very few of them can afford modern agricultural tools, because of their disadvantaged economic situations (Ahmed \& Cokinos, 2017), which makes local farmers even more vulnerable and leaves them without appropriate adaptive options. 
This is an author-produced, peer-reviewed version of this article. The final, definitive version of this document can be found online at Journal of Developing Societies, published by SAGE. Copyright restrictions may apply. doi: 10.1177/0169796X19868318

\section{Implications of Poor Rural Accessibility}

Kalapara is a relatively resource-poor region and has a very fragmented road network. Since it is one of the most disaster-prone areas in the country, cyclone shelters play critical roles saving lives during major tropical cyclones. In recent decades, human casualties have reduced in a substantial manner (Paul, 2009). Improvement of peoples' awareness and construction of multipurpose cyclone shelters played major roles in this positive change (Bern et al., 1993; GoB, 2008). However, the current capacities of existing cyclone shelters only can provide services to 18.87 percent of local vulnerable populations. The other 81.13 percent of them remain without access (CEGIS, 2009). The actual number of population who can access the services of cyclone shelters during any natural hazard are compromised because of low accessibility. If the road conditions are poor, some local people do not go to the cyclone shelters, because they think that going to these cyclone shelters on muddy or broken brick roads can cause further harm and loss to them.

"During Cyclone Sidr in 2007, people who attempted to go to cyclone shelters using local roads, got either seriously injured or drowned due to heavy water flows or damaged tree branches that fell on them"

(Response from a local farmer, Pakhimara Village, Kalapara; November 2017).

Women are already vulnerable to any natural hazard because of their unprivileged socioeconomic conditions (Faisal \& Kabir, 2005; IPCC, 2014). Particularly women, children, and elderly people tend to stay at home during natural disasters if the road access to cyclone shelters is poor.

These cyclone shelters (Figure 5) were constructed for multiple purposes, which means during cyclones, local people can go there and

Figure 5.

Multipurpose Cyclone Shelter Center in Kalapara

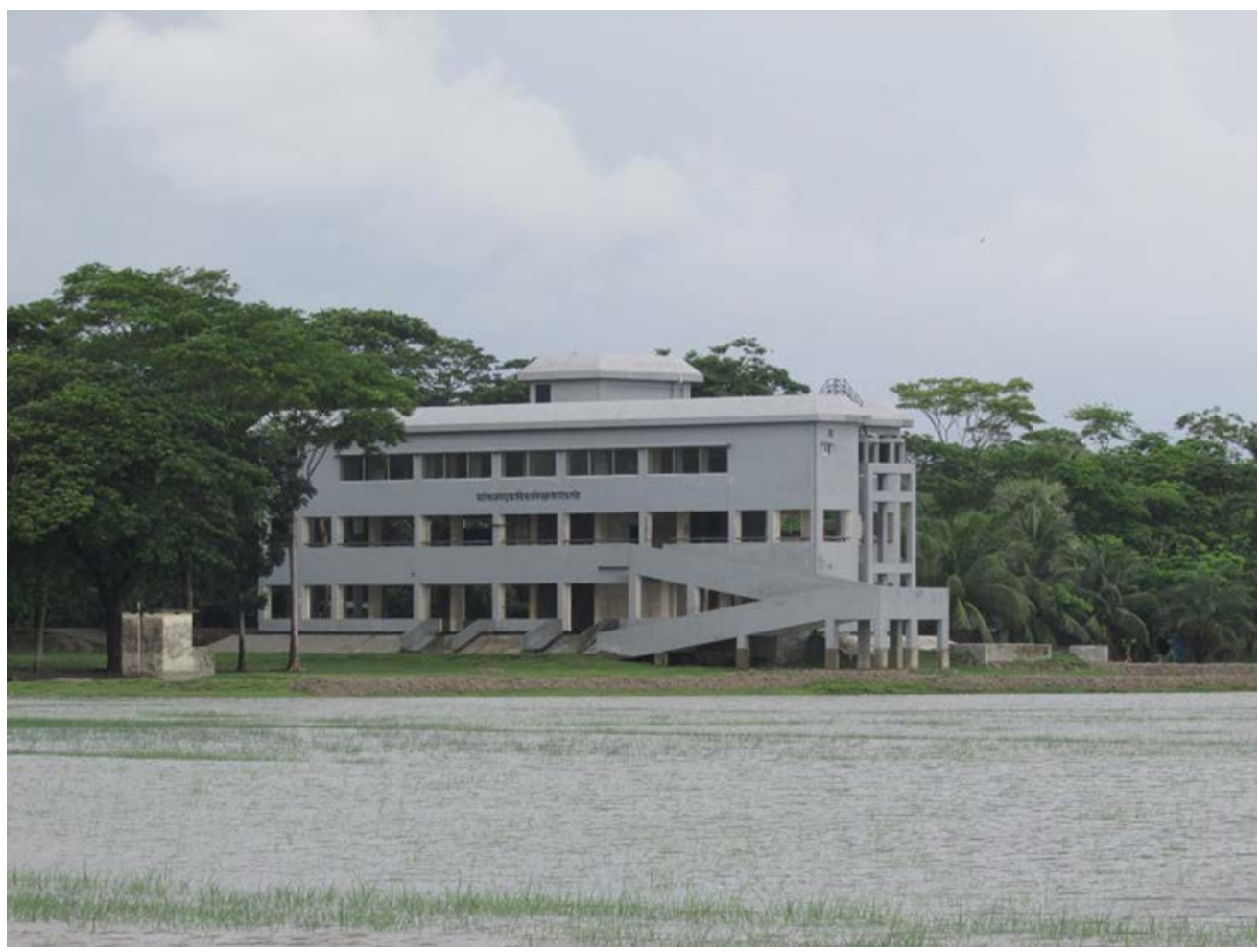

Source: The authors 
This is an author-produced, peer-reviewed version of this article. The final, definitive version of this document can be found online at Journal of Developing Societies, published by SAGE. Copyright restrictions may apply. doi: 10.1177/0169796X19868318

take shelter, and during other periods these shelters can be used for various purposes, such as schooling, health centers, etc. This suggests that poor accessibility in the region not only limits peoples' access to cyclone shelters during natural hazards or crisis, it also compromises people ability to get access to social services (Figure 6).

Inadequate rural roads and accessibility in villages of Kalapara not only affect peoples' willingness to go to and access to cyclone shelters, they can also contribute to deepen larger structural problems, and expand existing inequalities. First, poor rural accessibility in Kalapara affect farmers' income from their farm-related outputs. Due to poor road conditions, farmers need to pay more for bringing fertilizers, agricultural equipment, or selling crops in their farmlands. In situation of price increase of crops, usually farmers are not able to make profits, because they also spend higher prices for their crop transports. Lowering profit margins can force many farmers further into poverty, hunger, and food insecurity.

This can also affect peoples' access to various climate information and early warning systems. Due to the poor accessibility, Bangladesh Red Crescent volunteers, who play the major roles in disseminating early warning at the local level, most likely would not be in a position to warn 
This is an author-produced, peer-reviewed version of this article. The final, definitive version of this document can be found online at Journal of Developing Societies, published by SAGE. Copyright restrictions may apply. doi: 10.1177/0169796X19868318

Figure 6.

\section{Broken Bridge from the Kalapara Area Shows an Accessibility Challenge}

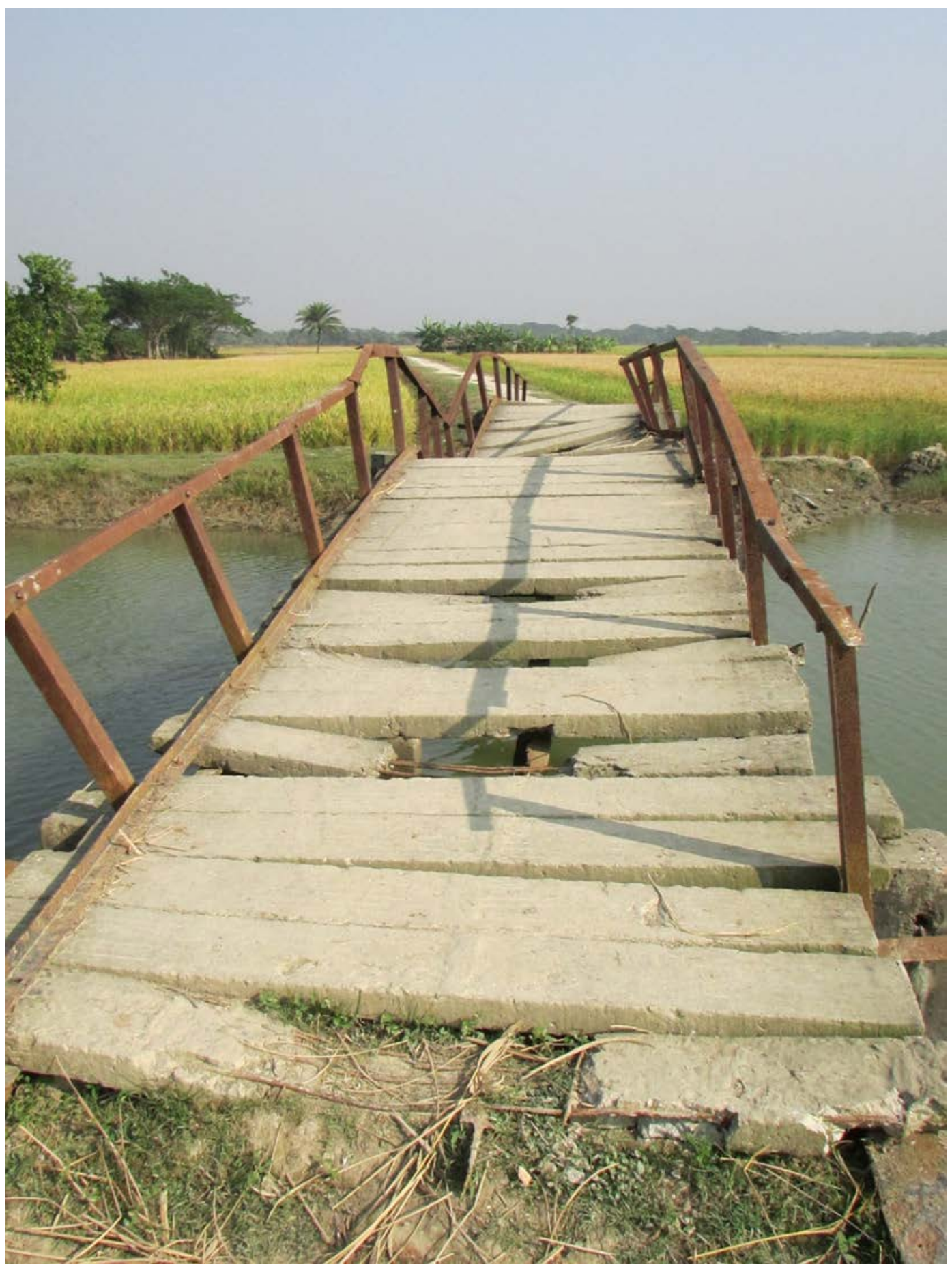

Source: The authors 
This is an author-produced, peer-reviewed version of this article. The final, definitive version of this document can be found online at Journal of Developing Societies, published by SAGE. Copyright restrictions may apply. doi: 10.1177/0169796X19868318

most of the local villagers in a short period of time. Also, agriculture extension agents, who travel village to village to disseminate various agro-meteorological information and play pivotal role in various agrobased innovation at the grassroots level, might get discoursed to reach marginal farmers or fishermen. Poor accessibility can also influence local peoples' willingness to use local health facilities, which is particularly critical for maternal and children health. Parents and children are also discouraged to enroll in schools due to the difficulty in travel from home to school.

Due to the poor and inadequate rural accessibility, the sufferings of local people are multifold. However, if we just consider the disaster preparedness and risk management aspects, it is very clear that poor accessibility causes major development burdens on farmers' livelihoods on all the aspects in Table 2.

Table 2.

\section{Implications of Inadequate Rural Accessibility on UNSDGs}

\begin{tabular}{|l|l|l|l|}
\hline Theme & $\begin{array}{l}\text { Challenges due to inadequate } \\
\text { rural accessibility }\end{array}$ & UNSDGs & Comments \\
\hline $\begin{array}{l}\text { Poor } \\
\text { accessibility }\end{array}$ & $\begin{array}{l}\text { Difficult to reach cyclone shelters } \\
\text { during any emergency situation }\end{array}$ & $\begin{array}{l}\text { Goal 13: Climate Action } \\
\text { Goal 11: Sustainable Cities } \\
\text { and Communities }\end{array}$ & $\begin{array}{l}\text { Since people have difficulty to reach } \\
\text { cyclone shelters, human casualties are } \\
\text { usually high. }\end{array}$ \\
\hline & $\begin{array}{l}\text { Red Cross volunteers might not be } \\
\text { in position to disseminate early } \\
\text { warning and other climate } \\
\text { information in short notice. }\end{array}$ & $\begin{array}{l}\text { Goal 13: Climate Action } \\
\text { Goal 11: Sustainable Cities } \\
\text { and Communities }\end{array}$ & $\begin{array}{l}\text { Since majority of local people do not } \\
\text { receive early warning and climate } \\
\text { information in time, peoples' capacities } \\
\text { to minimize damage are usually } \\
\text { compromised }\end{array}$ \\
\hline & $\begin{array}{l}\text { Because of poor accessibility } \\
\text { farmers will have limited access to } \\
\text { agro-meteorological information } \\
\text { and agriculture extension agents. } \\
\text { Both of these adversely affect } \\
\text { farmers' ability to grow crops and } \\
\text { income. }\end{array}$ & $\begin{array}{l}\text { Goal 1: No Poverty } \\
\text { Goal 2: Zero Hunger } \\
\text { Goal 12: Responsible } \\
\text { Consumption and } \\
\text { Production } \\
\text { Goal 13: Climate Action }\end{array}$ & $\begin{array}{l}\text { Since farmers' ability to grow crops are } \\
\text { compromised because of lack of agro- } \\
\text { meteorological information, farmers; } \\
\text { face increased level of farm loss. It } \\
\text { takes a large toll on farmers' } \\
\text { livelihoods. }\end{array}$ \\
\hline
\end{tabular}

Source: The authors.

\section{Conclusion}

Reducing poverty is a critical component of any nation that wants to achieve the 2030 UNSDGs. The multidimensional nature of poverty demands a focus on the ability to satisfy basic needs, such as access to employment opportunities, education, health services, and water and sanitation services (World Bank, 2000). Rural accessibility improvements can address this multidimensional nature of poverty by creating various livelihood opportunities. It can enhance people's access to markets, goods, and services, which are fundamental challenges for local farmers, and critical to achieve UNSDGs. At the same time, poor accessibility can create the vicious cycle of poverty by isolating people from services and opportunities. In resource-constrained societies, people spend substantial amounts of personal efforts to reach some destinations and to sell products (Biran, Abbot, \& Mace, 2004). These structural issues can adversely affect not only individual or household well-being, but also the nation's efforts to achieve larger development goals, such as the UNSDGs.

Even though there is a tendency among some development practitioners to distinguish community development projects from rural accessibility projects or disaster risk management interventions, all these aspects are closely intertwined. Without the successful implementation of one component, others can remain unattained, since poverty and livelihoods are multidimensional. Both the case studies from Bangladesh demonstrate that if we need to improve community well-being or capacity to respond to natural hazards, rural accessibility is vital.

The absence of adequate accessibility in rural areas negatively effects local livelihoods, the improvement of which is associated with many of the UNSDGs. Rural accessibility is the key to freeing the untapped human potential in societies like Bangladesh that face a number of major social, economic, and environmental challenges. For example, 
This is an author-produced, peer-reviewed version of this article. The final, definitive version of this document can be found online at Journal of Developing Societies, published by SAGE. Copyright restrictions may apply. doi: 10.1177/0169796X19868318

because of improved rural accessibility people can gain access to healthcare and education in addition to selling their products and engaging in mainstream economic activities. In this regard, it is important to note that lack of healthcare and education are both important causes and effects of poverty (Njenga \& Davis, 2003; World Bank, 1994).

Lack of accessibility can trigger multidimensional poverty and deprivation in rural communities in low-income countries such as Bangladesh. To make meaningful progress in these countries, it is critical to put rural infrastructure development and rural accessibility at the center of the sustainable development discourse. The two cases studies from Bangladesh show that in a low-income developing society, rural accessibility is critical and is a bridge between many of the goals of the UNSDGs. These findings also suggest that the achievement of the UNSDGs requires a comprehensive understanding of rural conditions and needs as well as a more nuanced understanding of rural policies and practices. The findings of this article also suggest that effective rural transport policies in the developing countries need to go beyond the technical and economic aspects of infrastructure projects, because in the long run, improved rural accessibility can spur many positive changes in people's lives and their relationship to the natural environment.

\section{DECLARATION OF CONFLICTING INTERESTS}

The authors declared no potential conflicts of interest with respect to the research, authorship, and/or publication of this article.

\section{FUNDING}

The first author received partial funding for this work from the American Philosophical Society's Lewis and Clark Fund for Exploration and Field Research.

\section{NOTE}

1. According to the World Bank studies on measuring rural accessibility: "Transport connectivity is an essential part of the enabling environment for inclusive and sustained growth. In many developing countries, particularly in Africa, the vast majority of farmers are still disconnected from local, regional, and global markets. To reduce poverty and support inclusive economic growth, rural access is key. The UN Sustainable Development Goals (SDGs) aim to build resilient infrastructure, promote inclusive and sustainable industrialization, and foster innovation (Goal 9), for which Target 9.1 is to develop quality, reliable, sustainable and resilient infrastructure...to support economic development and human wellbeing, with a focus on affordable and equitable access for all” (World Bank, 2016).

\section{REFERENCES}

Ahmed, S. (2017). Developmental crises impacting United Nations Millennium Development Goals achievement in Bangladesh: A critical review. In H. Besada, M. Agarwal, \& L. Polonenko (Eds.), The Global 2015 Development Agenda: Challenges and Prospects (pp. 289-308). Oxford, England: Policy Press.

Ahmed, S., \& Cokinos, C. (2017). How Does Ecological Modernization Explain Agriculture Adaptation in Coastal Bangladesh? A Critical Discussion. Environmental Hazards 16(2), 133-148.

Ahmed, S., \& Nahiduzzaman, K.M. (2016). Impacts of Rural Accessibility on Women Empowerment: The Case of Southwest Bangladesh. Transport and Communications Bulletin for Asia and the Pacific 86, 41-57.

Atuoye, K.N., Dixon, J., Rishworth, A., Galaa, S.Z., Boamah, S.A., \& Luginaah, I. (2015). Can she make it? Transportation barriers to accessing maternal and child health care services in rural Ghana. BMC Health Services Research, 15:333. DOI: 10.1186/s12913-015-1005-y

BBS. (2011). District Statistics 2011 - Chuadanga. Dhaka: Bangladesh Bureau of Statistics. Retrieved from http://www.bbs.gov.bd.

BBS. (2012). 2011 Population \& Housing Census: Preliminary Results. Dhaka: Bangladesh Bureau of Statistics.

Bangladesh National Portal. (2016). Chuadanga District - At a Glance. Retrieved from http://www.chuadanga.gov.bd.

Bern, C., Snieezek, J. Mathbor, G.M., Siddiqi, M.S., Ronsmans, C., Chowdhury, A.M., Choudhury, A.E., Islam, K., Bennish, M., Noji, E., \& Glass, R.I. (1993). Risk factors for mortality in Bangladesh cyclone of 1991. Bulletin of World Health Organization 71(1), 73-8. 
This is an author-produced, peer-reviewed version of this article. The final, definitive version of this document can be found online at Journal of Developing Societies, published by SAGE. Copyright restrictions may apply. doi: 10.1177/0169796X19868318

Biran, A., Abbot, J., \& Mace, R. (2004). Families and Firewood: A Comparative Analysis of the Costs and Benefits of Children in Firewood Collection and Use in Two Rural Communities in Sub-Saharan Africa. Human Ecology, 32 (1), 1-25.

CEGIS. (2009). Report on Cyclone Shelter Information for Management of Tsunami and Cyclone Preparedness. Dhaka: Centre for Environmental and Geographic Information Services, Ministry of Food and Disaster Management.

Chambers, R. (1983). Rural Development: Putting the Last First. London, UK: Pearson Education.

Darnhofer, I. (2010). Strategies of family farms to strengthen their resilience. Environmental Policy and Governance, 20, 212-222.

Edmonds, G. A. (1998). Wasted time - the price of poor access. RATP No.3. Geneva: Development Policies Department, International Labour Office.

Faisal, I.M. \& Kabir, M.R. (2005). An Analysis of Gender-Water Nexus in Rural Bangladesh. Journal of Developing Societies, 21(1-2), 175-194.

Foley, D., \& Chowdhury, J. (2007). Poverty, Social Exclusion and the Politics of Disability: Care as a Social Good and the Expenditure of Social Capital in Chuadanga, Bangladesh. Social, Policy and Administration, 41(4), 372-385.

GOB. (2008). Cyclone Sidr in Bangladesh: damage, loss and needs assessment for disaster recovery and reconstruction. Dhaka: Government of Bangladesh.

GoB. (2014). Upazila Disaster Management Plan (Upazila: Kalapara, District: Patuakhali). Patuakhali: Ministry of Relief and Disaster Management, Government of Bangladesh.

Gutierrez, J. (2009). Transport and Accessibility. International Encyclopedia of Human Geography 410-417.

Hogan, M., Foreman, K.J., Naghavi, M., Ahn, S.Y., Wang, M., Makela, S.M., Lopez, A.D., Lozano, R., \& Murray, C.J.L. (2010). Maternal mortality for 181 countries, 1980-2008: A systematic analysis of progress towards Millennium Development Goal 5. The Lancet, 375(9726), 1609-23.

Hoque, S. (2014). A Study of Adaptation Measures Practiced in Coastal Areas of Bangladesh in Response to Sea Level Rise. Master Thesis (Master of Urban and Regional Planning). Dhaka: Bangladesh University of Engineering and Technology.

IPCC. (2014). Climate Change 2014: Impacts, Adaptation, and Vulnerability. Part A: Global and Sectoral Aspects. Contribution of Working Group II to the Fifth Assessment Report of the Intergovernmental Panel on Climate Change. Cambridge, United Kingdom and New York, NY, USA: Cambridge University Press.

KfW. (2012). Ex Post-Evaluation Brief. Dhaka: Joint Project-Rural Markets and Roads, Khulna Division.

Koch, E., Thorp, J., Bravo, M., Gatica, S., Romero, C.X., Aguilera, H. \& Ahlers, I. (2012). Women's Education Level, Maternal Health Facilities, Abortion Legislation and Maternal Deaths: A Natural Experiment in Chile from 1957 to 2007. PLoS ONE, 7(5). DOI e36613. doi:10.1371/journal.pone.0036613

Kotir, J. H. \& Obeng-Odoom, F. (2009). Microfinance and Rural Household Development: A Ghanaian perspective. Journal of Developing Societies, 25(1), 85-105.

Kuhnle, R. (2005). Rural Infrastructure Development and Poverty Reduction: Example of Bangladesh. Manila. Asian Development Bank Institute.

LGED. (2016). LGED District portal - Chuadanga. Dhaka: Local Government Engineering Department. Retrieved from http://www.lged.gov.bd/

Njenga, P. \& Davis, A. (2003). Drawing the road map to rural poverty reduction. Transport Review, 23(2), 217-241.

Parvin, G.A., Shimi, A.C., Shaw, R. \& Biswas, C. (2016). Flood in Changing Climate: The Impact on Livelihood and How the Rural Poor Cope in Bangladesh. Climate, 4:60. DOI: 10.3390/cli4040060

Paul, B. K. (2009). Why relatively fewer people died? The case of Bangladesh’s Cyclone Sidr. Natural Hazards, 50, 289-304.

Pieterse, J.N. (2009). Development theory: Deconstructions/reconstructions. London: Sage.

Rapsomanikis, G. (2015). The economic lives of smallholder farmers: An analysis based on household data from nine countries. Rome: Food and Agriculture Organization of the United Nations.

Rostow, W.W. (1959). The Stages of Economic Growth. The Economic History Review, 12(1), 1-16.

Sen, A.K. (1999). Development as Freedoms. Oxford: Oxford University Press.

World Bank. (1994). Zambia poverty assessment (Vol. 1: Main Report). Washington, DC: The World Bank. (2000). World development report 2000. New York, NY: Oxford University Press.

(2016). Measuring rural access: Using new technologies. Washington, DC: World Bank Group. Retrieved from http://documents.worldbank. org/curated/en/367391472117815229/Measuring-rural-access-usingnewtechnologies 
This is an author-produced, peer-reviewed version of this article. The final, definitive version of this document can be found online at Journal of Developing Societies, published by SAGE. Copyright restrictions may apply. doi: 10.1177/0169796X19868318

Saleh Ahmed is an Assistant Professor in the School of Public Service at Boise State University. His research primarily focuses on climate change adaptation and resilience planning in the agrarian contexts of resourcepoor climate vulnerable regions. He is also an affiliated faculty member in the Human Rights Practice Program at the University of Arizona. [email: salehahmed@boisestate.edu]

Elizabeth Eklund is a doctoral candidate in the School of Anthropology at the University of Arizona. Her research is focused on environmental epistemology and the traditional uses of water, taking an ethnohistorical approach to climate and environmental variation. 